\title{
Linux-Based Server Operating System Installation Training for Yapdi Bandar Pulau Vocational High School Students
}

\author{
Pelatihan Instalasi Sistem Operasi Server Berbasis linux Pada Siswa \\ SMK Yapdi Bandar Pulau
}



\author{
Irianto*, Afrisawati, Sahren \\ Sekolah Tinggi Manajemen Informatika dan Komputer Royal; Kisaran; Indonesia; 21222; \\ *Correspondence: irianto2121212@gmail.com; \\ https:journal.aira.or.id/J-IbM | \\ Submission Received : 27-12-2021; Revised : 28-12-2021; Accepted : 30-12-2021; Published : 31-12-2021
}

\begin{abstract}
This community service activity aims to provide training to students of SMK Yapdi Bandar Pulau on Installing a Linux Server Operating System based on CentOS 7. Submission of material is carried out theoretically and directly in practice in installing a Linux server operating system. Several important points were conveyed theoretically and practically in this activity, such as an explanation of a Linux-based server or network operating system. Then in practice the participants were guided directly to perform the installation and basic configuration for this server operating system. Materials given to participants up to $90 \%$ of the knowledge about the Linux server operating system and how to install it. Based on the results of the discussions carried out in the form of question and answer discussions and direct practice, the understanding of the participants reached $92 \%$ for the level of understanding of the material provided.
\end{abstract}

Keywords: Installation, Linux, Operating System; Server

\begin{abstract}
Abstrak: Kegiatan pengabdian kepada masyarakat ini bertujuan memberikan pelatihan kepada siswa dan siswi SMK Yapdi Bandar Pulau tentang Instalasi Sistem Operasi server berbasis linux CentOS 7. Penyampaian materi diperbuat secara teoritis dan praktik langsung dalam melakukan instalasi sistem operasi server linux. Beberapa point penting yang disampaikan secara teoritis dan praktik dalam kegiatan ini seperti penjelasan mengenai sistem operasi server atau jaringan berbasis linux. Kemudian dalam praktiknya para peserta dipandu langsung untuk melakukan instalasi dan konfigurasi dasar untuk sistem oeprasi server ini. Materi yang diberikan ke peserta hingga 90\% dari pengetahuan tentang sistem operasi server linux dan cara instalasinya. Berdasarkan hasil pembahasan yang dilakukan berupa diskusi tanya jawab serta praktik langsung pemahaman para peserta mencapai 92\% untuk tingakat pemahaman pada materi yang diberikan.
\end{abstract}

Kata Kunci: Instalasi, Linux, Sistem Operasi, Scerver 


\section{Pendahuluan}

Kewajian setiap dosen sebagai telah dijelaskan dalam undang-undang yang berkaitan dengan Tridharma perguruan tinggi yaitu pendidikan penelitian dan pengabdian kepada masyarakat (Wibawa, 2017) (Ryansyah et al., 2019). Salah satu kewajian adalah Sekolah Tinggi Manajemen Informatika dan Komputer Royal Kisaran ialah melakukan pengadian kepada masyarakat kewajiban dilakukan sehubungan dengan kepedulian masing-masing dari lembaga atau organisasi yang berpartisipasi dalam pendidikan terutama pendidikan tinggi dengan seagai akibat dari perkembangan dan kemajuan teknologi khususnya Indonesia karena negara memiliki potensi sumer daya yang sangatlah besar.

Yayasan Pendidikan Dinul Islam, SMK Swasta Yapdi Bandar Pulau merupakan salah satu sekolah SMK yang ada di kabupaten asahan sumatra utara yang memiliki jurusan teknik komputer dan jaringan (TKJ). Pada jurusan ini salah satu fokus utamanya adalah membahas tentang teknologi jaringan komputer. Teknologi jaringan komputer yang sangat penting salah satunya adalah berkaitan dengan sistem operasi jaringan. Dimana sistem operasi jaringan menjadi central utama sebagai pusat untuk membangun server didalam jaringan. Pada jurusan TKJ pada SMK Yapdi Bandar Pulau sistem oeprasi jaringan yang telah dipelajari adalah linux debian dan Mikrotik OS pada Routerboard. Saat ini, adanya Linux di dunia teknologi tidak hanya menjadi alternatif sistem operasi, akan tetapi lebih dari itu, juga menjadi pemicu revolusi pemikiran di industri perangkat lunak (Harjono, 2016).

Sistem operasi Linux telah menjadi sangat penting dalam dunia industri dan komersial, karena merupakan sistem operasi open source (Wamiliana et al., 2013). Dimana memungkinkan pengguna untuk secara bebas menjalankan program untuk tujuan apapun, dari penelitian dan modifikasi program (Harjono, 2016). Linux telah menjadi sistem operasi dalam dirinya sendiri, dikenal karena stabilitas, skalabilitas, konfigurasi, dan di atas semua keandalan untuk tugas-tugas mission-critical (Sirait, 2018). Sistem operasi jaringan biasanya digunakan sebagai server untuk layanan seperti web server, database server, email server, FTP server dan lainnyaa (Sungkar et al., 2020). Pada kegiatan ini bertujuan untuk meberikan pelatihan berupa pengenalan dan tahapan instalasi terhadap sistem operasi jaringan yang belum dipelajari di mata pelajaran di SMK Yapdi Bandar Pulau ini. Dengan adanya kegiatan ini diharapkan memberikan para siswa pengalaman dan pengetahuan baru mengenai sistem operasi jaringan berbasis linux CentOS 7.

\section{Metode}

Didalam pelaksanaan kegitaan pengabdian kepada masyarat ini metode pendekatan yang dipakai ialah Participatory Action Research atau biasa disingat dengan PAR. PAR adalah salah satu cara untuk membangun jembatan yang menghubungkan orang dan ikut berpartisifasi dalam mengkaji guna melakukan perubahan ke lebih baik lagi (Rahman et al., 2021). PAR melibatkan melakukan penyelidikan untuk mendefinisikan masalah dan menerapkan informasi aktual sebagai solusi untuk masalah yang ditentukan (Muhtarom, 2019) . Dalam kegiatan pengabdian kepada masyarakat ini objectnya ialah SMK Yapdi Bandar Pulau dan para siswa/siswinya berperan sebagai subject . Adapun tahapan yang dilakukan dalam kegiatan ini adalah sebagai berikut: 
1. Indentifikasi Isu

Selama fase ini, tim menganalisis masalah di SMK Yapdi Bandar Pulau. Masalah diidentifikasi melalui observasi sekolah dan wawancara kekepala sekolah. Selain itu, fase ini menetapkan tujuan yang akan dicapai nantinya.

2. Penyusunan Materi Pelatihan

Pada fase ini tim Pengabdian kepada Masyarakat mengumpulkan materi yang ingin disampaikan selama kegiatan. Dokumentasi yang diberikan mencakup dasar-dasar jaringan komputer, sistem operasi jaringan, dan server CentOS Linux.

3. Penentuan Peserta

Penentuan peserta yang hendak mengikuti kegiatan ini dilakukan pada pase ini. Yakni Siswa SMK Yapdi Bandar Pulau untuk kelas 3 pada jurusan Teknik Komputer dan Jaringan, dengan jumlah peseta 20 orang siwa/i, yang akan mengikuti kegiatan pengabdian kepada masyarakat ini.

4. Pelaksannan Pelatihan

Kegiatan pelatihan akan dilaksanakan mulai pukul 09.00 hingga 12.00 WIB selama dua hari dari tanggal 22 Oktober (Jumat) hingga 23 (Sabtu), 2021. Diskusi pada hari pertama:
a. Intoduction Jaringan Komputer
b. Intoduction Sistem Operasi Server
Pada hari kedua membahas:

a. Proses Instalasi sistem operasi server berbasis Linux CentOS 7

b. Konfigurasi Jaringan pada Linux CentOS

\section{Hasil}

CentOS (Community Enterprise Operating System) adalah distribusi Linux, bagian dari upaya untuk menyediakan platform komputasi kelas enterprise yang sepenuhnya dikodekan biner yang kompatibel dengan kode sumber teratas, Red Hat Enterprise Linux. CentOS adalah salah satu sistem operasi yang direkomendasikan jika juga digunakan sebagai server. Ketika diimplementasikan pada CentOS, hampir semua kode dan perintah default hampir seluruhnya adalah mode teks. Secara default, CentOS memiliki perintah default. Dalam kegiatan pengabdian kepada masyarakat yang dilakasanakan di SMK Yapdi Bandar Pulau, Dusun I Desa Gonting Malaha, Kab. Asahan Sumatera Utara. Pihak sekolah dalam hal ini melaui kepala sekolah berharap melalui kegiatan ini dapat memberikan satu pengetahuan baru kepada para siswa yang ikut dalam kegiatan ini dalam bidang teknologi-teknologi bidang jaringan komputer terkhusus pada berbagai jenis sistem operasi jaringan berbasis linux, cara instalasinya dan penggunaannya. Kegiatan pengabdian masyarakat ini dilaksanakan oleh 3 orang dosen dengan rincian pada tabel 1 berikut ini.

Tabel 1. Deskripsi Tim

\begin{tabular}{|c|c|c|c|}
\hline No & Nama & Peran & Deskripsi \\
\hline 1 & Irianto, S.Kom., M.Kom & $\begin{array}{l}\text { Ketua } \\
\text { Tim }\end{array}$ & $\begin{array}{l}\text { Berperan sebagai ketua tim, guna } \\
\text { membagi peran setiap anggota. } \\
\text { Bertanggungjawab untuk memimpin }\end{array}$ \\
\hline
\end{tabular}




\begin{tabular}{|l|l|l|l|}
\hline No & Nama & Peran & Deskripsi \\
\hline & & & $\begin{array}{l}\text { diskusi penyusunan meteri pelatihan } \\
\text { dalam kegiatan masyarakat. Sebagai } \\
\text { instruktur/dosen yang menyampaikan } \\
\text { materi pelatihan kepada peserta }\end{array}$ \\
\hline 2 & Afrisawati, S.Kom., M.Kom & Anggota & $\begin{array}{l}\text { Bertanggungjawab untuk menyusun } \\
\text { materi serta sebagai instruktur/dosen } \\
\text { yang membimbing saat pelatihan } \\
\text { berlangsung }\end{array}$ \\
\hline 3 & Sahren, S.Kom., M.Kom & Anggota & $\begin{array}{l}\text { Bertanggungjawab untuk menyusun } \\
\text { materi serta sebagai instruktur/dosen } \\
\text { yang membimbing saat pelatihan } \\
\text { berlangsung }\end{array}$ \\
\hline
\end{tabular}

\section{Mulai Proses Instalasi Linux Cent0S7}

Proses instalasi merupakan tahapan awal untuk membagun suatu infrastruktur server pada jaringan komputer (Roihan, 2015). Tahapn instalasi ini terbagi dua pertama adalah instalasi perangkat keras dan kedua adalah instalasi perangkat lunak. Dalam kegiatan ini instalasi yang dilakukan adalah tahapn yang kedua atau tahapan instalasi perangkat lunak berupa sistem operasi. Hal pertama yang perlu disiapkan adalah USB/DVD bootable yang berisi CentOS. Setelah Anda memiliki CentOS yang dapat di-boot, ketik centos yang dapat di-boot dan mulai ulang PC Anda untuk mulai mem-boot ke CentOS.

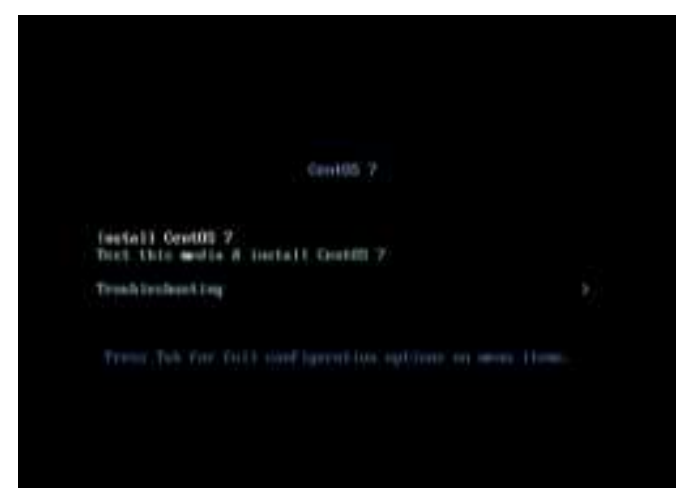

Gambar 1. Proses Boot Linux CentOS

Sistem mengunduh penginstal dan segera menampilkan layar selamat datang. Kemudian lanjutkan ke langkah memilih bahasa instalasi. Pilih bahasa yang ingin Anda gunakan untuk CentOS dan kemudian klik tombol "Lanjutkan".

\section{Installation Summary}

Di sini Anda dapat mengatur tanggal, tata letak keyboard, partisi hard disk, dan alamat IP. Selanjutnya hal yang penting adalah memilih partisi disini kita dapat memilih menu instalation destination.

Disini kita dapat mengatur partisi hardisk, dan alokasinya. anda dapat memilih "Automatically configure my partitioning" lalu klik "Done" dan lanjut ke proses instalasi 
selanjutnya yaitu setting tanggal dan jam. Atau, klik "I will configure partitioning" lalu klik done untuk merubah partisi dan alokasi system. Seperti pada gambar 2 berikut ini.

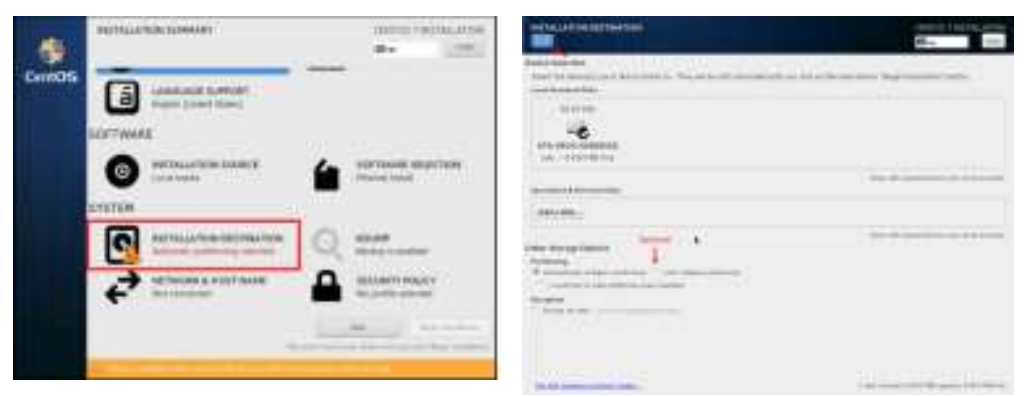

Gambar 2. Menu Partisi

Klik "Click here to create them automatically" sebagai bagian dasar. Kemudian akan dihadapkan pada proses mempartisi harddisk. Secara default, partisi CentOS hanya membutuhkan 3 partisi: root (/), swap, dan direktori home (/ home). Proses untuk mendefinisikan bagian tergantung pada persyaratan server yang digunakan, dan penulis memberikan contoh bagian yang digunakan untuk server. Ada beberapa partisi penting yang diperlukan saat membuat server: root (/), swap, dan cache. Partisi pertama adalah partisi root, di mana digunakan sebagai lokasi sistem file utama dari berbagai layanan dimulai. Kedua swap digunakan untuk bantuan memori utama. Kita dapat mengubahnya jika perlu. Swap bertindak seperti RAM tambahan bagi sistem operasi. Ketika pemisahan dan distribusi selesai, klik tombol Finish. Klik tombol "Accept Changes" untuk menyimpan perubahan serta melanjutkan ketahap berikutnya.

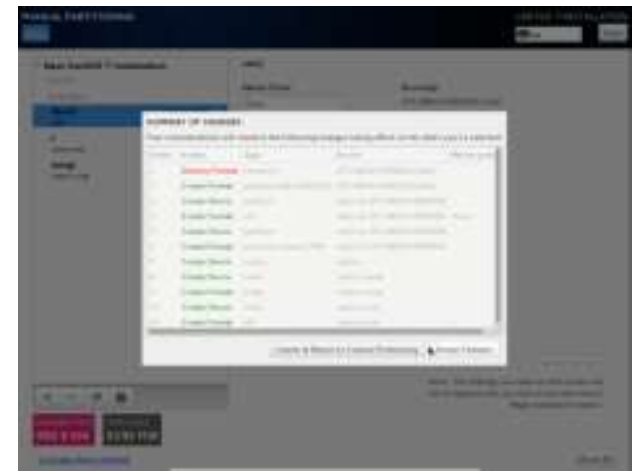

Gambar 3. Applay Partisi

\section{Mulai Proses Instalasi}

Kita masih dapat mengatur beberapa parameter lain seperti keyboard, pemilihan perangkat lunak, dan IP. Jika tlah merasa sudah cukup, klik Berikutnya. "Begin Installation" untuk memulai proses instalasi. Lalu kita dapat membuat user dan password, serta memberikan password pada root seperti pada gambar 4 berikut.


Gambar 4. Memulai Proses Instalasi dan Membuat User 
Klik "Root Password" untuk merubah password root. Klik "User Creation" untuk menambahkan user lain. Untuk User bisa disesuaikan dengan kebutuhan yang ada. Isi kolom yang diperlukan untuk membuat pengguna. kita dapat menjadikan pengguna sebagai administrator (hak istimewa dengan sudo) dengan mencentang kotak "Jadikan pengguna ini sebagai administrator". Tunggu hingga proses instalasi selesai, lalu klik tombol Restart untuk me-restart komputer Anda. Setelah selesai proses instalasi. Selanjutnya pada tahapan selanjutnya perlu dilakukan beberapa konfigrasi dasar yang dibutuhkan untuk sistem operasi jaringan yang akan digunakan. Diantara konfigurasi dasar yang perlu dilakukan seperti melakukan konfigurasi IP Address dengna cara mengetikkan command dhclient (untuk mendapatkan IP otomatis dari jaringan). Lalu selanjutnya melakukan update repository dengan mengetikkan perintah yum -y update. Lalu install yum plugins agar dapat mendapatkan mirror yang terbaik saat melakukan update, upgrade maupun install aplikasi dengan command yum -y install yum-pliginsfastestmirror.

Setelah kegiatan pelatihan yang dilakukan usai, maka tim dosen membagikan kuisioner kepada para peserta dalam kegitan ini yaitu para siwa dan siswi. Dimana kuisioner berisi 9 pertanyaan yang akan digunakan sebagai pengukur kegiatan ini berjalan dengan sangat baik atau tidak.

Tabel 2 Hasil Kuisionel Paska Selesai Pelatihan

\begin{tabular}{|c|c|c|c|c|}
\hline \multirow[b]{2}{*}{ No } & \multirow[b]{2}{*}{ Isi Pertanyaan } & \multicolumn{3}{|c|}{ Penilaian } \\
\hline & & Cukup & Baik & $\begin{array}{l}\text { Baik } \\
\text { Sekali }\end{array}$ \\
\hline 1 & Apakah Durasi Sesi Pelatihan Memadai & - & $5 \%$ & $95 \%$ \\
\hline 2 & $\begin{array}{l}\text { Apakah Perlengkapan Untuk Penyampaian } \\
\text { Materi Baik }\end{array}$ & - & $10 \%$ & $90 \%$ \\
\hline 3 & Apakah Tim Dosen/Instruktur Komunikatif & $2 \%$ & $11 \%$ & $87 \%$ \\
\hline 4 & $\begin{array}{l}\text { Apakah Tim Dosen/Instruktur Interaktif } \\
\text { Terhadapa Peserta }\end{array}$ & $3 \%$ & $12 \%$ & $85 \%$ \\
\hline 5 & $\begin{array}{l}\text { Apakah Tim Dosen/Instruktur Menguasai } \\
\text { Materi }\end{array}$ & $3 \%$ & $7 \%$ & $90 \%$ \\
\hline 6 & $\begin{array}{l}\text { Apakah Materi Yang Disampaikan Bisa } \\
\text { Dimengerti }\end{array}$ & $2 \%$ & $5 \%$ & $93 \%$ \\
\hline 7 & Apakah Kegiatan ini Bermanfaat bagi Peseta & & $6 \%$ & $94 \%$ \\
\hline 8 & $\begin{array}{l}\text { Apakah Materi Yang Disampaiakan Mengikuti } \\
\text { Perkembangan atau Tren Teknologi Saat ini }\end{array}$ & - & $12 \%$ & $88 \%$ \\
\hline 9 & $\begin{array}{l}\text { Apakah Peserta Puas Dengan Jawaban yang } \\
\text { diberikan terhadap pertanyaan peserta }\end{array}$ & $2 \%$ & $8 \%$ & $90 \%$ \\
\hline
\end{tabular}

Dari hasil penilaian kuisioner para peserta kegiatan pelatihan instalasai sistem operasi server berbasis linux ini berjalan dengan sangat baik. 


\section{Diskusi}

Sistem operasi merupakan salah satu komponen penting dari sebuah sistem komputer (Dalimunthe et al., 2020). Sistem operasi bertanggung jawab untuk mengelola penggunaan perangkat keras komputer seperti prosesor, memori, perangkat input/output, dan media (Nurrahman, 2020). Sistem operasi juga berfungsi sebagai lapisan yang menghubungkan perangkat keras komputer dengan perangkat lunak(Nugraha, 2019). Berdasarkan hasil diskusi dan wawancara dengan para siswa maupun para guru banyak sekali hal-hal yang menjadi bahasan diantaranya berkaitan mengenai tren penggunanan sistem operasi jaringan berbasis linux dan hambatan yang sering terjadi ketika menggunakan sistem operasi berbasis linux yang diperuntukan untuk jaringan yang cenderung berbasis teks untuk melakukan konfigurasi ataupun instalasi setiap packet softwarenya. Maka dari itu dalam kegiatan ini kami beserta tim terus mendorong dan membimbing para peserta pelatihan untuk lebih dapat memahami setiap bentuk instruksi-instruksi yang ada pada saat instalasi sistem operasi linux CentOS 7 dan konfigurasi dasar yang dilakukan. Berikut beberapa foto dokumentasai kegiatan yang dilakukan.

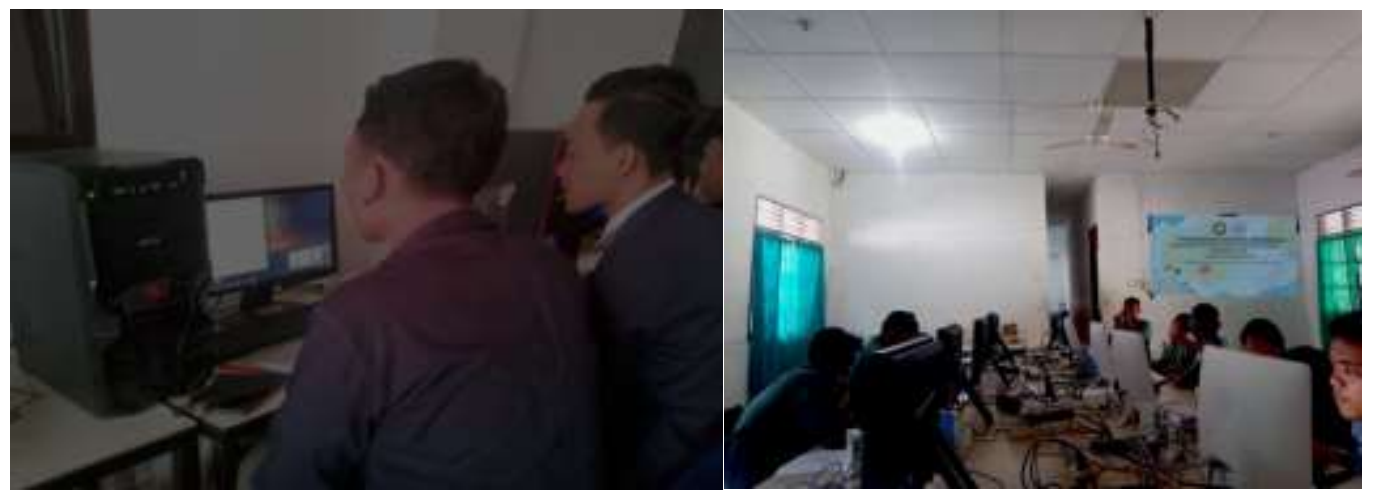

Gambar 5. Foto Dokumentasi Kegiatan

\section{Kesimpulan}

Berdasarkan kegiatan PKM yang dilaksanakan pada SMK Yapdi Bandar Pulau, dapat ditarik kesimpulan sebagai berikut: Pekerjaan secara umum yang dilakukan oleh tim instruktur/dosen STMIK Royal Kisaran ini berhasil mencapai tujuannya. Materi kegiatan yang diberikan kepada peserta dapat digunakan untuk memperluas pengetahuan mereka tentang sistem operasi server berbasis Linux dan metode instalasi. Materi yang disampaikan kepada peserta mencakup semua konsep sistem operasi server dan $90 \%$ cara menginstal server Linux. Materi presentasi terdiri dari beberapa sesi: penjelasan, pelalatihan, dan diskusi.

\section{Daftar Referensi}

Dalimunthe, R. A., Yusda, R. A., \& Ramdhan, W. (2020). Instalasi Sistem Operasi Berbasis Windows 10 Pada Sekolah Man Kisaran. Jurdimas (Jurnal Pengabdian Kepada Masyarakat) Royal, 3(2), 163-168. https://doi.org/10.33330/jurdimas.v3i2.499

Harjono, E. B. (2016). Analisa Dan Implementasi Dalam Membangun Sistem Operasi Linux Menggunakan Metode LSF Dan REMASTER. Informatika, I(1), 30-35. 
Muhtarom, A. (2019). Participation Action Research dalam Membangun Kesadaran Pendidikan Anak di Lingkungan Perkampungan Transisi Kota. Dimas: Jurnal Pemikiran Agama Untuk Pemberdayaan, 18(2), 259. https://doi.org/10.21580/dms.2018.182.3261

Nugraha, N. I. (2019). ANALISIS KEMANAN SISTEM OPERASI WINDOWS , LINUX, dan MAC OS Analisis Kemanan Sistem operasi. January, 0-6.

Nurrahman, F. (2020). Implementasi Linux Ubuntu Server 18.04 Sebagai Server Sistem Informasi Akademik Pada Sekolah Tinggi Manajemen Informatika Dan Komputer Samarinda. Jurnal DiJITAC, 1(1), 55-77.

Rahman, A. S., Sembodo, C., Kurnianingsih, R., Razak, F., \& Al Amin, M. N. K. (2021). Participatory Action Research Dalam Pengembangan Kewirausahaan Digital Di Pesantren Perkotaan. Ulumuddin: Jurnal Ilmu-Ilmu Keislaman, 11(1), 85-98. https://doi.org/10.47200/ulumuddin.v11i1.766

Roihan, A. (2015). Instalasi dan Konfigurasi Server Dalam Satu Perangkat Komputer Sebagai Media Pembelajaran Altenatif.

Ryansyah, M., Ernawati, S., Yulia, E. R., Bagus, R., Putra, D., \& Yusuf, L. (2019). PENGENALAN INSTALASI SISTEM OPERASI NOTEBOOK BERBASIS WINDOWS UNTUK ANAK ASUH REMAJA PADA YAYASAN PENDIDIKAN. 1(2), 5-10.

Sirait, P. (2018). Pemanfaatan Sistem Operasi Linux Sebagai Webserver Studi Kasus Linux Fedora 22.

Sungkar, M. S., Albab, U., \& Bayyaummi, A. M. (2020). RANCANG BANGUN WEB SERVER MENGGUNAKAN SISTEM OPERASI DEBIAN 7 DI. 8(2), 1-4.

Wamiliana, Wardhana, W., \& Kharismaldie, F. (2013). Pembangunan Sistem Operasi Berbasis Linux Menggunakan Metode Linux From Scratch. Jurnal Komputasi, 1(2), 30-37. http://jurnal.fmipa.unila.ac.id/index.php/komputasiHal.30dari94

Wibawa, S. (2017). Tridharma Perguruan Tinggi (Pendidikan Dan Pengabdian Kepada Masyarakat). Ristek-Dikti, 29, 1-15. 